Psychological Medicine, 1988, 18, 545-549

Printed in Great Britain

\title{
EDITORIAL
}

\section{Psychiatry for the rich: a history of the private madhouse at Ticehurst in Sussex, 1792-19171}

Despite a recent burgeoning of interest in the history of psychiatry and institutions for the insane, there has hitherto been no full-length study of the history of a private asylum in England. ParryJones' (1972) survey of private madhouses in England in the eighteenth and nineteenth centuries mapped out a fertile territory for potential future research, but with the exception of his own detailed look at Hook Norton and Witney asylums in Oxfordshire, the archives of private madhouses remain largely unexplored. Recent monographs on the history of individual institutions for the insane (Digby, 1985; Thompson, 1984, in the American context, Tomes, 1985) have focused instead on the history of private charity, or publicly funded hospitals. For this reason alone, a longer historical examination of the internal working of a private madhouse, and its location in a broader social and medical context, would have been worthwhile. But my own study of the history of Ticehurst Asylum (MacKenzie, 1987) also aimed to explore the evidence from one private madhouse in the light of current debates in the historiography of psychiatry; and to draw attention to issues which have not so far been raised by the agenda of 'provocative questions' (Scull, 1986) which is the legacy of the wide-ranging historical surveys of the 1960s-70s (Foucault, 1969; Doerner, 1981; Scull, 1979).

Ticehurst, indeed, would make a poor test case by which to assess Doerner's thesis that the main thrust behind psychiatric institutionalization was an offensive by the bourgeoisie against the idleness of the insane poor; or Scull's argument that the development of a mature capitalist economy fostered social conformity and a desire to segregate the disruptive and deviant from the community, freeing those who might otherwise have been tied at home by lunatic dependants to enter the market-place. Although for the first 30-35 years after it opened in 1792 Ticehurst accommodated some pauper patients, from the outset the asylum's clientele were predominantly private, and became increasingly upper-class as the nineteenth century progressed. As Digby and Tomes have argued, in relation to the York Retreat and Pennsylvania Hospital respectively, it is difficult to apply arguments of 'social control' to institutions with a mainly bourgeois clientele, and this is even more clearly so in the case of Ticehurst, which unlike the Tukes' or Kirkbride's asylums had no avowed charitable and philanthropic intentions behind its foundation (Digby, 1985, p. 8 Tomes, 1985, pp. xi, 12, ch. 3). Tomes' work points fruitfully to the asylum's servicing the needs of the family, as an alternative source of explanation for the success of the Pennsylvania Hospital and, similarly, I aimed to explore the ways in which the Newington family, who ran Ticehurst through four generations from 1792-1917, succeeded in satisfying the requirements of their fee-paying clientele: that is, patients' families rather than the patients themselves.

It seems important to make it clear that, unlike some social scientists and historians, I do not see mental illness simply as a social construct, and asylum inmates as necessarily family or other social scapegoats. Like Nancy Tomes, I believe mental illness 'involves both physiological and social processes'; and, I would want to add, psychological ones, which it may ultimately be possible to describe physiologically but which are currently best analysed phenomenologically (see Tomes, 1985 , p. xii). However, I do not see it as the historian's task to make retrospective diagnoses or discuss whether or not asylum inmates were 'really' ill. It is more important for the historian to elaborate the way in which asylum inmates were perceived by their contemporaries and by themselves, and this is aided by a deliberate suspension of judgement and an even-handed approach

1 Address for correspondence: Dr C. MacKenzie, The Wellcome Institute for the History of Medicine, 183, Euston Road, London NWI 2BP. 
to all the varying contemporary interpretations of what was happening to the patient. Equally, I believe psychiatry can best be described in its social aspects by historians who are concerned with its place in the whole contemporary culture, rather than in a delineation of psychiatric 'discoveries' and 'advances'. I was therefore concerned with psychiatry's medical effectiveness only in so far as this was one factor which influenced the way in which asylum practice was perceived by the general public; and an equally important and continuous theme was how well psychiatry related to prevailing standards and ideals of moral and social behaviour. As Shepherd (1983) has argued, psychiatry is 'closely embedded in the social matrix in which the subject is practised'; and one of the values of the history of psychiatry is to help illuminate that matrix.

Unlike the Retreat, which after the publication of Samuel Tuke's Description of the Retreat (1813) stood as the reformers' symbol of enlightened asylum practice, Ticehurst did not enjoy a particularly prominent reputation in the early nineteenth century; nor, on the other hand, did it become notorious for malpractice, like Thomas Warburton's Red and White Houses in Bethnal Green. In 1877, Lord Shaftesbury told a Commons select committee that to close down Ticehurst 'would be a positive loss to science and humanity' (Select Committee, 1877), but there is little evidence of when and how this substantial late nineteenth century reputation was quietly established. To twentieth-century historians of psychiatry however, Ticehurst has become something of a symbol: it is one of the four private madhouses apart from Hook Norton and Witney which Parry-Jones (1972, pp. 119-121) describes in some detail, suggesting that 'Throughout the nineteenth century, Ticehurst held a high reputation as an asylum for the wealthier classes'; perhaps on account of this exceptional reputation it is the institution which Scull primarily focuses on to argue that "rich [Victorians] could buy greater attention and more eminent psychiatrists for their crazy relatives, but not more cures' (Scull, 1979, pp. 205-208); and it is one of the asylums which Porter (1981-2) has cited as operating de facto principles of moral treatment before the influence of Pinel and Samuel Tuke. How far the lavish imagery of Ticehurst in the mid-late nineteenth century - the aristocratic patients, extensive grounds, a pack of harriers and numerous staff - can be extended to Ticehurst's early history with historical accuracy is one of the main questions my own work explored.

For the early period the only records available are accounts, so that it is difficult to do more than tenuously speculate about the reasons why Ticehurst was originally established, and the medical and moral philosophy which informed treatment under Samuel Newington (1739-1811). As Ticehurst's village surgeon and apothecary, Samuel Newington was reputed to have had single patients in his care for thirty years before the asylum was opened. Unlike some other late eighteenth-early nineteenth-century asylum-founders, such as Edward Fox in Bristol and William Tuke in York, Samuel Newington had no known non-conformist religious affiliations. However, the available evidence suggests that the mechanical restraint and drastic depletion once thought to have been typical of eighteenth-century methods of treatment of the insane were not resorted to routinely. On the contrary, patients were encouraged to take exercise and given a liberal diet, and as far as possible their attention was engaged in mental diversions such as music, painting, sewing and reading.

Following Samuel Newington's death in 1811, he was succeeded by two of his sons, Charles (1781-1852) and Jesse (d. 1819). After 1817, the published writings of Thomas Mayo (1817, 1831, 1834,1838 ), who was visiting physician to Ticehurst from 1817-36, and a published account by a former patient, John Perceval $(1838,1840)$, of his stay at Ticehurst in 1832, mean that there is substantial evidence to locate Ticehurst in the 1820 s and 1830 s within the broader trends of social change. The ways in which Ticehurst was influenced by the Evangelicals' call for a thoroughgoing reform of the manners and morals of the nations, and Thomas Mayo's role in the development of a diagnosis of 'moral insanity', can be elaborated. Like Thomas Szasz today, Mayo emphasized the moral responsibility of the insane subject; but unlike Szasz, Mayo used this line of reasoning to defend an active and interventionist psychiatric medicine. A revision of the standards by which family life should be conducted was central to the Evangelicals' campaign, and Charles Newington's and Thomas Mayo's ability to appear as part of the apparatus for moral reform, through removing and seeking to 're-educate' disruptive family members, enhanced the asylum's appeal to the middle 
classes. It was during this period that Ticehurst was transformed into a more exclusive and upperclass institution. Perceval's and Mayo's writings make it possible to describe more fully the kind of medical and moral treatment which was offered at Ticehurst in the 1820s-1840s than in the first years after the asylum opened, but the prevailing image of a system of treatment based on exercise, tonic diets, only moderate depletion (by bleeding and/or purging) and a fostering of the patient's interest in the outside world, remained the same.

The study of a single institution provides an opportunity to explore the impact of national trends and changes in medical theory and practice on local, and in the case of Ticehurst, familial traditions. Increased documentation required by the 1845 Lunacy Act makes it possible to draw a clearer profile of the asylum's inmates after 1845, in terms of their age, marital status and social class. In addition, the medical casebooks kept as a result of this legislation mean that far more is known about the moral and medical treatment of patients, so that it was possible to critically assess Scull's verdict, that the main form of treatment offered by institutions like Ticehurst was 'moral treatment . . . with a vengeance' (Scull, 1979, p 207). I have attempted to show that the relationship between mind and body, and moral and medical treatment, was perceived in Victorian psychophysiology as one of fluid interchange rather than rigid separation. Scull's description misrepresented Ticehurst in two important ways. First, while moral therapy was clearly central to treatment at Ticehurst it was practised alongside medical therapeutics which were regarded as being of at least equal importance by Charles Hayes (1813-63) and Samuel Wilmot Newington (1815-82), who had succeeded their father as joint proprietors of the asylum in 1852. The emphasis on the growth and importance of moral therapy has obscured the stress in Victorian medico-psychological practice on the interaction and mutual influence of the body and the mind-that is, on psychophysiology.

Scull's mocking dismissal of treatment in institutions like Ticehurst as 'moral therapy. . . with a vengeance' underestimates the seriousness of the historical actors' genuine therapeutic aspirations. Scull also underestimated Ticehurst's turnover of patients, but more importantly his emphasis on 'cure' rather than 'care' is historically misleading: the Newingtons were able to satisfy the perceived needs of their clientele, who may have hoped for a cure or recovery, but knew that in many cases the most they could reasonably expect was respectful and considerate nursing. While Scull is generally critical of the medical model of insanity, he shares its prejudice in favour of therapeutic results rather than quality of care. As Nancy Tomes has argued, in the American context, the midnineteenth century may have represented a high-point in the care of the chronic insane, and even by Victorian standards Ticehurst was exceptionally well provided in terms of staff and entertainments (Tomes, 1985, pp. 319-321).

Herbert Francis Hayes Newington (1847-1917), who became joint proprietor of Ticehurst with his uncle Samuel in 1875, was more active than his predecessors in the Medico-Psychological Association, of which he was president in 1889-90. His more prominent professional career provided the basis for a discussion of Ticehurst's location within the profession of psychiatry, during a period of considerable agitation for the closure of private asylums, and a relatively bleak era for therapeutic initiatives and research. Hayes Newington's published writings enrich a reading of his day-to-day treatment of patients in Ticehurst, making it possible to assess the continuing importance of moral precepts to his practice as a psychiatric physician. Although a social profile of the asylum's inmates during this later period was drawn, Hayes and his cousin Alexander Newington's (1846-1914) relationships with patient's families were described in less detail. The Ministry of Health's directive on the confidentiality of hospital patient records (HM (61) 73) does not cover private hospital records, but I have followed its recommendation that patients should not be individually named until their records are 100 years old. A full elaboration of the social context of referral and committal was therefore not possible after 1886. Instead, the way in which Hayes Newington strove to secure the asylum's future at a political and professional level was described; and $I$ hope that this will illuminate the particular difficulties faced by psychiatry as it failed to keep pace with the rapid developments taking place in other fields of medicine in the late Victorian-Edwardian era. While we now have a rich historiography of Victorian medical 
psychology, with the exception of Clark's thesis (Clark, 1982) on British psychiatric theory between 1850 and 1900 , relatively little work had previously been done on this later period.

Current debates surrounding the closure of mental hospitals tend to stereotype everything that is undesirable with the epithet 'Victorian'. Reid \& Wiseman (1986) stated 'Victorian values should have no place at a time when we are supposedly moving away from the Victorian legacy of larger remote and inappropriate mental hospitals.' While large, remote buildings are a legacy of the midnineteenth century, the image of stark and environmentally impoverished asylum wards may more accurately be one which belongs to the late nineteenth and twentieth-century, following the development of the biomedical model, and increased separation of 'curable' and 'incurable' patients. The late Victorian-Edwardian period saw some falling away from high standards of care for the chronic insane at Ticehurst, linked to the growth of a therapeutically pessimistic model of insanity as hereditary degeneration, as well as the development of the biomedical model which favoured dramatic results. Clark has documented the growth of a determination within psychiatry, in the later nineteenth century, to shed responsibility for chronic patients; and the fact that Hayes Newington espoused a concentration of resources on the 'hospital' treatment of acute cases of insanity was typical of his profession in this respect. In addition, Clark has seen this drive as a response to psychiatry's low status within the medical profession, and an attempt to map out a province in preventive and curative medicine rather than custodial care. While this would seem to be a plausible assessment, both Clark and Scull have perhaps exaggerated psychiatry's political ineffectiveness in the later nineteenth century (Clark, 1982, pp. 304, 306.) An examination of the role of the Medico-Psychological Association's parliamentary committee (of which Hayes Newington was a member), makes it clear that it had considerable impact on the drafting of the 1890 Lunacy Act, particularly in its treatment of the private sector.

A statistical survey of the available records was carried out for the entire period 1792-1917; and the resulting analysis formed the basis for much of the argument which I have developed. However, it seems important to stress that Ticehurst was a relatively small institution, never housing more than about eighty patients at any one time, and any attempt to generalize from these statistics about overall psychiatric trends in nineteenth-century Britain would be misguided. Similarly, while I wanted to emphasize that in its early history Ticehurst was more 'ordinary' than its current image in the historical literature suggests, I do not see it as representative of nineteenth-century psychiatric practise as a whole: wherever possible, the evidence from Ticehurst was linked to what is known of other individual asylums through the work of Parry-Jones, Anne Digby and Margaret Thompson, but these comparable studies reflect as many differences as similarities between Ticehurst and other asylums.

One of the main arguments of my thesis is that, if Ticehurst was influenced by national trends, it was also to some extent exceptional; and of course the standards of care for which Ticehurst's clientele were able to pay cannot be taken as 'typical' of Victorian England. If Charles Hayes' and Samuel Newington's underlying preconceptions - their belief in the healing powers of nature, shunning of heroic medication, and faith in a supportive regimen and mental diversions - were shared by some of their colleagues, Ticehurst's financial resources meant that it was nevertheless unusual in its ability to carry these objectives into effect. Unusual, but not unique: Digby's work on the Retreat suggests that even in a larger registered hospital the early-mid nineteenth century was a period of relatively individualized, medically benign treatment. Both Ticehurst and the Retreat clearly incorporated strong ethical beliefs into their therapeutic objectives which reflected social preoccupations; but nevertheless, as Tomes has argued of the Pennsylvania Hospital, from a humanitarian standpoint the level of care achieved, particularly of chronic patients, is deserving of respect (Tomes, 1985, p. 321). Turner (1985) has suggested that the range of provisions available to Ticehurst's clientele in the mid-nineteenth century might provide one possible model for a present-day balance between community and small-scale institutional care. While generous financial resources would be a prerequisite of achieving such high levels of care, the deterioration in standards of treatment at Ticehurst in the later nineteenth century suggests that even lavish resources are no guarantee of such standards. If there are any lessons to be learnt from the history of Ticehurst, it 
might rather be that what made possible the standards of care achieved in the mid-nineteenth century was an equally high evaluation of 'caring' and 'curing', of science and humanitarianism, which was later disrupted by the advent of the biomedical model, and the priority allocation of resources to the treatment of acute, potentially curable, cases.

\section{MACKENZIE}

\section{REFERENCES}

Clark, M. (1982). 'The Data of Alienism': Evolutionary Neurology, Physiological Psychology, and the Reconstruction of British Psychiatric Theory, c. 1850-c. 1900. D. Phil, thesis, University of Oxford, p. 304.

Digby, A. (1985). Madness, Morality and Medicine. A Study of the York Retreal, 1796-1914. Cambridge University Press: Cambridge.

Doerner, K. (1981). Madmen and the Bourgeoisie: A Social History of Insanity and Psychiatry. Blackwell: Oxford.

Foucault, M. (1967). Madness and Civilisation. A History of Insanity in the Age of Reason. Tavistock Publications: London.

MacKenzie, C. (1987). A Family Asylum: A History of the Private Madhouse at Ticehurst in Sussex, 1792-1917. Ph D. thesis, University of London. (To be published in book form by Tavistock Press.)

Mayo, T. (1817). Remarks on Insanity: Founded on the Practice of John Mayo, M.D. T. \& G. Underwood: London.

Mayo, T. (1831). An Essay on the Influence of Temperament in Modifying $D_{y s p e p s i a}$ or Indigestion. B. Fellowes: London.

Mayo, T. (1834). An Essay on the Relation of the Theory of Morals to Insanity. B. Fellowes: London.

Mayo, T. (1838). Elements of the Pathology of the Human Mind. J. Murray: London.

Parry-Jones, W. L.I. (1972). The Trade in Lunacy. A Study of the Private Madhouses in England in the Eighteenth and Nineteenth Centuries. Routledge \& Kegan Paul: London.

Perceval, J. (1838 \& 1840). Narrative of the Treatment Experienced by a Gentleman During a State of Mental Derangement. Designed to
Explain the Causes and the Nature of Insanity, and to Expose the Injudicious Conduct Pursued Towards Many Unfortunate Sufferers Under That Calamity. Effingham Wilson: London. (Reprinted by Gregory Bateson, Percevar's Narrative. A Patient's Account of Mis Psychosis, 1830-1832. William Morrow: New York, 1974.)

Reid, H. \& Wiseman, A. (1986). When the Talking Has to Stop. Community Care in Crisis; the Case of Banstead Hospital. MIND: London.

Scull, A. (1979). Museums of Madness. The Social Organization of Insanity in Nineteenth-Century England. Allen Lane: London.

Scull, A. (1986). A Generous Confidence. Thomas Story Kirkbride and the Art of Asylum-Keeping, 1840-1883. (Book review.) Journal of Social History 19, 521-2.

Select Committee (1877). Report from the Select Committee on Lunacy Laws: together with the Proceedings of the Commiltee, Minutes of Evidence, and Appendix (PP1877. XIII. 1-), p. 546.

Shepherd, M. (1983). The Psychosocial Matrix of Psychiatry. Collected Papers. Tavistock Publications: London, p. IX.

Thompson, M. S. (1984). The Mad, the Bad and the Sad: Psychiatric Care at the Royal Edinburgh Asylum (Morningside), 1813-1894. Ph.D. thesis, University of Boston.

Tomes, N. (1985). A Generous Confidence. Thomas Story Kirkbride and the Art of Asylum-Keeping, 1840-1883. Cambridge University Press: Cambridge.

Tuke, S. (1813). Description of the Retreat. An Institution near York for Insane Persons of the Society of Friends. W. Alexander: York.

Turner, T. H. (1985). The past of psychiatry: why build asylums? Lancet ii, 709-711. 